Rev Inves Clin. 2017;69:94-102

\title{
GENETIC CANCER RISK ASSESSMENT FOR BREAST CANCER IN LATIN AMERICA
}

\author{
Yanin Chavarri-Guerra ${ }^{1,2}$, Kathleen Reilly Blazer ${ }^{2}$ and Jeffrey Nelson Weitzel ${ }^{2 *}$ \\ ${ }^{1}$ Department of Hemato-Oncology, Instituto Nacional de Ciencias Médicas y Nutrición Salvador Zubiran, Mexico City, \\ Mexico; ${ }^{2}$ Division of Clinical Cancer Genomics, City of Hope Comprehensive Cancer Center, Duarte, CA, USA
}

\begin{abstract}
In Latin America, breast cancer is the most common malignancy in women, and limited available data suggest that up to $15 \%$ of all breast cancer cases in the region are hereditary. Genetic cancer risk assessment and counseling is a critical component of the appropriate clinical care of patients with hereditary breast cancer and their families. Unfortunately, genetic services are underdeveloped across Latin America, and access to genetic testing and counseling is very scarce in the region. Barriers contributing to the access to genetic care are high cost and lack of insurance coverage for genetic tests, insufficient oncogenetics training or expertise, nonexistence of genetic counseling as a clinical discipline, and lack of supportive healthcare policies. In this review, we highlight relevant initiatives undertaken in several Latin American countries aimed at creating genetic cancer risk assessment programs. Additionally, we present a review of the scientific literature on the current status of breast cancer genomics in Latin America, with specific emphasis on demographic indicators, access to cancer genetic care, training and strategies to improve outcomes, and international collaborations. (Rev Inves Clln. 2017;69:94-102)
\end{abstract}

Key words: Breast cancer. Genetic counseling. Genetic testing. Healthcare disparities. Latin America.

\section{INTRODUCTION}

Breast cancer is the most common malignancy in women worldwide, with nearly 1.7 million cases diagnosed in 2012 , representing $25 \%$ of all female cancers ${ }^{1}$. Over the next 20 years, the incidence and mortality of breast cancer in developing countries are projected to increase by more than $50 \%{ }^{2}$. In Latin America, breast cancer is also the most common malignancy and the leading cause of cancer-related mortality among women ${ }^{3}$. The mean age at diagnosis in Latin America is generally 10 years younger than that reported in developed countries, which may be explained in part by a combination of demographics (greater proportion of younger women at risk), recent changes in lifestyle risk factors, and an elevated frequency of hereditary cancer syndromes in some countries ${ }^{4}$. Moreover, young women with breast cancer are more frequently diagnosed with triple-negative breast cancer subtype, which has a worse prognosis when compared to other subtypes and a higher probability of being associated with hereditary cancer predisposition ${ }^{5}$.

\section{Corresponding author:}

*Jeffrey N. Weitzel

Division of Clinical Cancer Genetics

City of Hope Comprehensive Cancer Center

1550 East Duarte Rd

Duarte, CA 91910, USA

Email: jweitzel@coh.org 
During the last 60 years, advances in early detection, novel therapies and diagnostic tools, and preventive care that includes genetic testing for cancer predisposition have largely contributed to a remarkable improvement in breast cancer survival in the developed world 6 . In contrast, the breast cancer incidence/mortality ratio in Latin America remains high, which can in part be attributed to more advanced disease at diagnosis and limited access to cancer care ${ }^{3}$. Although, progress is being made in Latin America, access to genetic cancer risk assessment (GCRA) and testing services remains an underdeveloped component of cancer care $^{7}$.

Hereditary breast cancer accounts for approximately $10 \%$ of all breast cancers. The genes most commonly associated with hereditary breast cancer are BRCA1 and $B R C A 2(B R C A)^{8}$. Women who carry a pathogenic germline mutation in one of the BRCA genes are estimated to have a cumulative breast cancer risk between 43 and $76 \%$ by the age of 70 years, and up to a $59 \%$ risk to develop ovarian cancer ${ }^{9}$.

The prevalence of BRCA mutations in Latin America is comparable to that of more developed countries, ranging from 1.2 to $4.9 \%$ in unselected breast cancer cases $^{10}$. Identifying women with increased breast and ovarian cancer risk due to an inherited $B R C A$ mutation allows for more effective breast screening to facilitate the diagnosis of smaller, more curable cancers, and laparoscopic salpingo-oophorectomy, tamoxifen, and mastectomy for cancer prevention, and enables the assessment of cancer risk among other family members, often prior to the onset of disease ${ }^{11}$.

As a result, guidelines from the National Comprehensive Cancer Network (NCCN) and from several international societies recommend genetic testing for individuals who meet specific personal and/or family cancer history criteria ${ }^{12}$. Unfortunately, diagnostic genomic tools and genetic counseling services require complex technology and specialized personnel that are unavailable for the majority of people living in limited-resource settings ${ }^{13}$.

The objective of this review is to provide an overview of GCRA for breast cancer in the Latin American region, with specific emphasis on demographic indicators, access to cancer genetic care, training, and strategies to improve outcomes.

\section{BREAST CANCER GENETICS IN LATIN AMERICA}

Latin America is a heterogeneous region comprised of 33 countries with diverse healthcare systems, resources, socioeconomic status, culture, geography, and ethnicity. The inhabitants of Latin America represent the most genetically admixed population in the world, reflecting a unique historical pattern of migration and interaction with other populations ${ }^{14}$. Genetic studies have shown a wide range of variation in ancestry admixture by country. In Brazil, for example, the highest levels of European ancestry are found in the south of the country, while African ancestry is higher in the northwest (Amazonia). In Chile, European and Native American ancestries are relatively uniform, although European ancestry is a little higher in urban areas. In Peru, Native American is the predominant ancestry throughout the country, while African ancestry is generally low except for in the northern coast. In Mexico, the highest Native American ancestry is found in the central and southern regions of the country, while European ancestry is more common in the north and African ancestry is found in the coastal regions. The distribution of these ancestral patterns is the consequence of a complex history marked by the European colonization of America ${ }^{15}$. Given that European genetic ancestry has been associated with a higher breast cancer risk in Latin America ${ }^{16}$, these ancestral patterns may contribute to an explanation for the geographic distribution of the disease.

Knowledge of breast cancer-associated gene mutations in the region is limited, and most studies have focused on BRCA mutations. The BRCA mutations are responsible for approximately $40 \%$ of hereditary breast and ovarian cancer cases in general, which are inherited in an autosomal dominant fashion ${ }^{17}$. These gene mutations are found at a higher frequency among certain ethnic groups. For example, one in 40 unselected individuals of Ashkenazi Jewish decent carry one of the three founder mutations: 185 delAG or 5382 ins $C$ in BRCA1 or 6174 delT in BRCA $2^{18}$. In the Caucasian population, the prevalence of BRCA mutations is estimated to be one in 300 individuals ${ }^{19}$. In Latin America, the prevalence in unselected breast cancer cases ranges from 1.2 to $4.9 \%$, which is similar to that reported for the non-Hispanic population living in USA ${ }^{10}$. Table 1 shows the prevalence for BRCA 
Table 1. BRCA mutation prevalence in selected countries in Latin America

\begin{tabular}{|c|c|c|}
\hline Country & Cohort selecting criteria & $B R C A$ prevalence \\
\hline Argentina 68,69 & $\begin{array}{l}\text { Personal or } \mathrm{FH} \text { of } \mathrm{BC} / \mathrm{OC} \\
\mathrm{BC} / \mathrm{OC} \text { in } \leq 40 \mathrm{y}) ; \mathrm{FH} \text {; or } \mathrm{AJ} \text { ancestry }\end{array}$ & $19.04-28.3 \%$ \\
\hline Bahamas $^{20,21}$ & $\begin{array}{l}\mathrm{BC} \\
\text { Unaffected women with } \mathrm{FH} \text { of } \mathrm{BC} / \mathrm{OC}\end{array}$ & $\begin{array}{l}23 \% \\
2.8 \%\end{array}$ \\
\hline Brazil70-75 & $\begin{array}{l}\text { BC unselected cases } \\
\mathrm{FH} \text { of } \mathrm{BC} / \mathrm{OC} \\
\mathrm{BC} \text { with } \mathrm{FH} \\
\mathrm{HBOC} \text { criteria } \\
\mathrm{OC} \text { unselected }\end{array}$ & $\begin{array}{c}2.3 \% \\
3.4 \% \\
13 \% \\
2.8-26 \% \\
35.5 \%\end{array}$ \\
\hline Chile $^{76-79}$ & $\mathrm{BC} / \mathrm{OC}$ with $\mathrm{FH}$ & $7.1-20.4 \%$ \\
\hline Colombia $29,30,45$ & $\begin{array}{l}\mathrm{BC} \text { patients } \\
\mathrm{BC} / \mathrm{OC} \text { families } \\
\mathrm{OC} \text { patients }\end{array}$ & $\begin{array}{l}1.2 \% \\
24.5 \% \\
15.6 \%\end{array}$ \\
\hline Costa Rica ${ }^{22}$ & $\mathrm{BC}$ with $\mathrm{FH}$ & $4.5 \%$ \\
\hline Cuba $^{23}$ & BC patients & $2.6 \%$ \\
\hline Mexico $43,46,80-82$ & $\begin{array}{l}\text { BC/OC unselected cases } \\
\text { Early BC } \\
\text { TNBC }\end{array}$ & $\begin{array}{c}4.3-28 \% \\
6 \% \\
23 \%\end{array}$ \\
\hline Peru $^{44}$ & Unselected cohort & $5 \%$ \\
\hline Puerto Rico 24 & $\mathrm{BC}$ and unaffected individuals with $\mathrm{FH}$ & $47.8 \%$ \\
\hline Uruguay 25 & $\mathrm{BC}$ with $\mathrm{FH}$ & $17 \%$ \\
\hline Venezuela $^{83}$ & $\mathrm{BC}$ cases with $\mathrm{FH}$, early onset or bilateral $\mathrm{BC}$ & $17.2 \%$ \\
\hline US Hispanics ${ }^{10}$ & Unselected BC patients & $1.2-4.9 \%$ \\
\hline
\end{tabular}

BC: breast cancer; FH: family history; HBOC: hereditary breast and ovarian cancer; OC: ovarian cancer; AJ: Ashkenazi Jewish; TNBC: triple negative breast cancer; y: years.

mutations for selected countries in Latin America. Within the region, the highest frequency of BRCA mutations has been reported in the Bahamas, with $23 \%$ of women with breast cancer and $2.8 \%$ of unaffected women with family history of breast/ovarian cancer having $B R C A$ mutations ${ }^{20,21}$.

In the majority of Latin American populations, BRCA1 is the gene most frequently found to have pathogenic mutations, with the exception of Costa Rica ${ }^{22}, \mathrm{Cuba}^{23}$, Puerto Rico ${ }^{24}$, and Uruguay ${ }^{25}$ where BRCA2 is more common. The most common variants reported in Latin America are shared with other populations such as the Ashkenazi BRCA1 founder mutations 185delAG and $5382 \mathrm{ins} C$, and the Spanish BRCA1 founder mutation $R 71 G^{26,27}$, exemplifying again a pattern of historical population migration ${ }^{10}$. However, there are other mutations that are frequent in Latin America and uncommon in other populations, such as BRCA1 A1708 $\mathrm{E}^{10}$. Founder mutations have also been reported in Mexico (BRCA1 ex9-12del) 28; in Colombia (BRCA1 3450del4, A17082 and BRCA2 3034del4) 29,30 ; and in Brazil (BRCA1 5382insC and BRCA2 c.156_157insAlu) ${ }^{31,32}$. Although the majority of BRCA mutations consist of single base changes or deletions/insertions of small numbers of bases, large rearrangements of DNA segments have been reported twice as frequently in the Latin American populations. Large rearrangements detected in Latin America are BRCA1 deletions of exons $1-2$, exons $9-12$, exon 14 , exons $16-17$, as well as deletion of the entire gene ${ }^{28,33,34}$.

The prevalence of other highly penetrant hereditary breast cancer genes, such as PTEN (Cowden's syndrome), TP53 (Li-Fraumeni syndrome), STK11 (PeutzJeghers syndrome) and $\mathrm{CDH} 1$ (hereditary diffuse gastric cancer) is largely unknown in Latin America ${ }^{32}$. An exception to this is the finding of the TP53 R337H founder mutation in Brazil. The spectrum of associated tumor types is slightly atypical for Li-Fraumeni syndrome and the prevalence of the allele has been calculated to be 1:300 individuals in the Rio Grande du Sul region, which is higher than the estimated worldwide prevalence (1:2000-1:5000)35,36.

PALB2 has been recently described as a breast cancer predisposing gene with an average cumulative breast cancer risk of $35 \%$ ( $55 \%$ if there is a family history 
of breast cancer) ${ }^{37}$. A recurrent PALB2 mutation (c.2167delAT) has been found in Hispanics as well as in Italian and Nigerian families ${ }^{38}$.

\section{ACCESS TO GENETIC CANCER RISK ASSESSMENT}

Genetic cancer risk assessment (GCRA) is an interdisciplinary medical practice in which genetic and genomic tools are used to identify individuals and families at risk of having an inherited cancer syndrome. The clinical practice of GCRA includes risk assessment, genetic testing, and management of individuals at risk ${ }^{39}$. Although GCRA is available in most cancer centers in the USA and in other developed nations, this is not the case in low- and middle-income countries in Latin America, where access to GCRA is limited.

\section{AVAILABILITY OF GENETIC TESTING IN LATIN AMERICA}

The majority of gene mutations are detectable by standard methods such as Sanger sequencing of polymerase chain reaction (PCR) amplified DNA segments. In a few cases (large rearrangement mutations), alternative assays are required such as Southern blotting, multiplex ligation-dependent probe amplification (MLPA), quantitative PCR, or comparative genomic hybridization ${ }^{33}$. Historically, these are prohibitively expensive testing methods for low- and middle-income countries. Commercial testing for BRCA in the USA has been available for 20 years. In Latin America, however, genetic testing for BRCA or other cancer-predisposing mutations is not widely available and, when offered, it is often unaffordable for patients ${ }^{3}$. While technological advances such as next generation (massively parallel) sequencing (NGS) has rendered sequencing considerably cheaper, the cost of genetic testing in the USA still ranges from US\$ 249 to 5,000 , depending on the type of test ordered ${ }^{40,41}$, and is not affordable for most public healthcare systems in Latin America. In order to overcome the barrier represented by the high cost of genetic testing, academic centers in the region have partnered with national or international collaborative research projects and offer testing as part of research initiatives ${ }^{42}$.
A low-cost genetic screening tool that incorporates recurrent BRCA mutations observed in Hispanic women has been developed and implemented throughout Latin America ${ }^{30,43-46}$. HISPANEL is a panel of 114 recurrent Hispanic BRCA mutations analyzed by a Sequenom MassARRAY ${ }^{\circ}$ platform and a PCR assay to screen for the large genomic rearrangement of $B R C A 1$ exon 9-12. This test has been reported with a sensitivity of $68 \%$ to detect BRCA mutations in a Mexican population, at a cost of US\$2043. Another potentially cost-effective solution would be to perform the HISPANEL genetic test followed by a full sequencing of the gene if HISPANEL-negative on an Ion Torrent PGM platform and analyzing the copy number of variations (CNV) by MLPA. The cost of this approach has been calculated to be US\$ 25 for mutations found by HISPANEL and US\$ 117.25 for the samples requiring MLPA ${ }^{47}$. This panel is currently available for research purposes in five Latin American countries (Brazil, Colombia, Mexico, Peru, and Puerto Rico).

\section{REGIONAL GUIDELINES}

Paradoxically, even though genetic testing is seldom available and not included in public insurance schemes, several Latin American countries have national guidelines recommending genetic counseling and testing in selected cases based on personal and family history of cancer ${ }^{48-51}$. Additionally, these guidelines include risk-reduction intervention recommendations for women with hereditary breast cancer syndromes, many of which are also not covered by public health insurance ${ }^{40}$.

Table 2 summarizes national recommendations for genetic testing and risk-reduction intervention in selected countries.

\section{GENETIC CANCER RISK ASSESSMENT PROGRAMS IN LATIN AMERICA}

Clinical Cancer Genetics in Latin America is a less developed field than in other regions of the world. Some of the barriers precluding its development in the region are: limited awareness of GCRA by patients and physicians; unavailability of genetic testing; limited or lack of coverage for costly testing; genetic 
Table 2. National practice guidelines for hereditary breast and ovarian cancer syndromes in selected countries in Latin America

\begin{tabular}{|c|c|c|c|c|}
\hline Country & National Guidelines & Genetic Counseling Criteria & $\begin{array}{l}\text { Screening and } \\
\text { management } \\
\text { recommendations }\end{array}$ & $\begin{array}{l}\text { Healthcare } \\
\text { public } \\
\text { insurance } \\
\text { coverage }\end{array}$ \\
\hline Argentina $^{51}$ & $\begin{array}{l}\text { Guidelines for the } \\
\text { detection and study of } \\
\text { high-risk hereditary } \\
\text { breast cancer cases. } \\
\text { National Intersociety } \\
\text { Consensus for high risk } \\
\text { of breast cancer. ( } 2014 \text { ) }\end{array}$ & $\begin{array}{l}\mathrm{BC}<50 \text { y; bilateral/ } \\
\text { multicentric } \mathrm{BC} ; \mathrm{BC} \text { in male; } \\
\mathrm{BC} \text { in } \mathrm{AJ} ; \geq 2 \text { first/second } \\
\text { degree relative; } \mathrm{BC} \text { plus other } \\
\text { primary or; } \mathrm{TNBC}<60 \mathrm{y} \text {. } \\
\text { Families with } \mathrm{BC} \text { plus } \mathrm{OC} \text {; } \mathrm{BC} \\
\text { plus endometrial or thyroid } \\
\text { cancer; } \mathrm{BC} \text { plus pediatric } \\
\text { cancer or; } \mathrm{BC} \text { plus } \mathrm{Gl} \text { cancer. }\end{array}$ & $\begin{array}{l}\text { Annual breast MRI and } \\
\text { mammogram } \\
\text { RRM. } \\
\text { RRSO after child bearing } \\
\text { completion (BRCA mutation). } \\
\text { Chemoprevention if RRM not } \\
\text { performed. }\end{array}$ & No \\
\hline Brazil $^{50}$ & $\begin{array}{l}\text { Operational Manual. } \\
\text { National Hereditary } \\
\text { Cancer Network. (2009) }\end{array}$ & $\begin{array}{l}\mathrm{BC} \geq 3 \text { cases plus } \mathrm{OC} \text { case; } \\
\mathrm{BC}>3 \text { cases } \leq 50 \text { y or; } 2 \\
\text { sisters or mother and } \\
\text { daughter }<50 \text { y with one of } \\
\text { the followings: } 2 \text { BC cases; or } \\
2 \text { OC cases; or BC plus OC. }\end{array}$ & $\begin{array}{l}\text { Monthly breast self exam. } \\
\text { Annual or every } 6 \text { months } \\
\text { clinical breast exam. } \\
\text { Annual mammogram. } \\
\text { Breast MRI ( } 6 \text { months after } \\
\text { the mammogram) } \\
\text { Transvaginal ultrasound plus } \\
\text { Ca } 125 \text { (every } 6 \text { months). }\end{array}$ & No \\
\hline Colombia48 & $\begin{array}{l}\text { Guideline for the early } \\
\text { detection, treatment, } \\
\text { follow-up, and } \\
\text { rehabilitation of breast } \\
\text { cancer. (2013) }\end{array}$ & $\begin{array}{l}\mathrm{BC}<30 \mathrm{y} \text {; } \mathrm{BC} \text { in } 2 \text { FDR }<40 \text { y; } \\
\text { or } 3 \text { FDR }<50 \text { y; or } 4 \text { FDR } \\
<60 \text { y; or } 6 \text { relatives (any } \\
\text { age); } \\
\text { BC plus FDR < } 50 \text { y; OC plus } \\
\text { BC in FDR < } 50 \text { y; OC in } 2 \\
\text { FDR; bilateral OC recurrent } \\
\text { OC after } 2 \text { y of initial } \\
\text { diagnosis; OC < } 40 \text { y; BC or } \\
\text { OC in AJ Ancestry; male BC } \\
\text { or; BC or OC < } 50 \text { y plus } \\
\text { other BRCA-related cancer } \\
\text { (BC, OC, endometrium, } \\
\text { colon, small bowel, gastric, } \\
\text { biliary, pancreatic, prostate, } \\
\text { melanoma or sarcoma). }\end{array}$ & $\begin{array}{l}\text { Annual breast MRI or } \\
\text { mammogram plus US } \\
\text { (if MRI is not available } \\
\text { or contraindicated). } \\
\text { RRM } \\
\text { RRSO } \\
\text { Chemoprevention. }\end{array}$ & No \\
\hline Mexico $^{49}$ & $\begin{array}{l}\text { Mexican Official Norm } \\
\text { (NOM-041-SSA2-2011) } \\
\text { for breast cancer } \\
\text { prevention, diagnosis, } \\
\text { treatment and } \\
\text { surveillance. }\end{array}$ & $\begin{array}{l}\text { Personal history of } \mathrm{BC}<40 \mathrm{y} \text {; } \\
\text { bilateral } \mathrm{BC}, \mathrm{BC} \text { plus } \mathrm{OC} ; \\
\text { Family history of } \mathrm{BC} \text { in } \geq 2 \\
\text { FDR; } \mathrm{BC} \text { in male; relative with } \\
\mathrm{BC} \text { plus } \mathrm{OC} ;>1 \text { generations } \\
\text { with cancer (colon, pancreas, } \\
\text { prostatic); > } 1 \text { OC; AJ } \\
\text { ancestry; high-risk gene } \\
\text { mutation. }\end{array}$ & $\begin{array}{l}\text { Breast self examination; } \\
\text { Clinical breast exam every } 6 \\
\text { months; } \\
\text { Annual breast image } \\
\text { (mammogram, ultrasound or } \\
\text { MRI according to age and } \\
\text { resources; } \\
\text { Annual social and } \\
\text { psychological support. } \\
\text { Chemoprevention; } \\
\text { RRSO } \\
\text { RRM }\end{array}$ & No \\
\hline
\end{tabular}

AJ: Ashkenazi Jewish; BC: breast cancer; FDR: first degree relative; Gl: gastrointestinal; HBOC: hereditary breast and ovarian cancer; MRI: magnetic resonance imaging; OC: ovarian cancer; RRM: risk reduction mastectomy; RRSO: risk reduction salpingoophorectomy; TNBC: triple-negative breast cancer; y: years.

counseling not being recognized as a clinical discipline; few educational opportunities in cancer genetics; absence of healthcare policies and lack of infrastructure 10,40,52,53. In addition, most existing programs are located in academic hospitals in large urban areas, making them practically inaccessible to people living in rural regions ${ }^{10,54}$. While most Latin American nations do not have organized GCRA programs, various successful GCRA efforts have been implemented in the region. 


\section{Argentina}

In 2011, the National Plan for Hereditary and Familiar tumors (PROCAFA) was created by the National Cancer Institute of Argentina. The aims of PROCAFA are training healthcare professionals in cancer genetics; developing diagnostic and therapeutic guidelines; creating a network of genetic services across the country and starting a hereditary cancer registry. Two years after PROCAFA was instituted, the Argentinean Familiar Cancer Network (RACAF) was created to address the last two objectives (creating a network of services and a registry). As of 2015, RACAF included 44 health professionals from 36 public and private institutions distributed all over the country. The RACAF programs are aimed at promoting patient case discussions and developing educational activities for healthcare providers ${ }^{54}$.

\section{Brazil}

Clinicians from Brazil are pioneers in genetic cancer counseling in Latin America. GCRA in Brazil started in the 1990s with a few individual academic clinics funded by research grants. Researchers and clinicians from those centers became organized in the Brazilian Hereditary Cancer Network (BHCN), which in 2011 published the first Brazilian guidelines for the detection, diagnosis, counseling, testing, and surveillance of hereditary cancer syndromes. Currently, 10 centers from cities across Brazil provide GCRA to patients enrolled in the federal universal Public Health Care System (SUS). One of the major challenges that this network has faced since its inception is financial constraint due to little coverage for genetic testing in public health plans. However, since 2012, genetic testing is included in private insurance schemes, which provide coverage to approximately one third of the Brazilian population ${ }^{55}$.

\section{Mexico}

In 2016, the National Cancer Institute of Mexico (IN(AN) opened the first Hereditary Cancer Clinic in the country. The clinic has a multidisciplinary team of healthcare professionals including genetic specialists, molecular biologists, cytogenetic experts, and general physicians that coordinate the referral of patients with a suspicious diagnosis of hereditary cancer syndrome.
Initiation of the GCRA program services was facilitated by a dissemination and implementation intervention in collaboration with the Division of Clinical Cancer Genomics at the City of Hope Cancer Center in Duarte, California. This included Avon Foundation and Breast Cancer Research Foundation sponsored participation in an established intensive clinical training program, provision of $B R C A$ gene testing for patients enrolled in a collaborative research registry, local infrastructure assessment, and academic detailing for the administration and staff to promote GCRA program development and recognition. Genetic testing is performed to confirm or rule out the diagnosis, and recommendations are made based on the testing results to both the patients and their families ${ }^{56}$. More recently, in the north region of the country, a Hereditary Cancer Clinic was also established in Monterrey following the same working model used at INCAN ${ }^{57}$. In the short term, they also plan to replicate the model in another state of the country (Coahuila). Cancer genetic services are also available in the state of Jalisco, where clinician scientists from the Instituto Jalisciense de Cancerología and the Civil Hospital located at Guadalajara also participated in the GCRA program development intervention and are part of the City of Hope international collaborative research registry to study familial cancer epidemiology and clinical outcomes ${ }^{58,59}$.

\section{Peru}

In 2008, the Genetic and Molecular Biology Unit at the National Institute of Neoplastic Diseases of Peru started the first genetic cancer program in the country, which serves as a referral center for patients with cancer diagnosis and their families nationwide. Cancer genetic training and genetic testing have been facilitated through a research collaboration with City of Hope. During the first five years, the program has provided genetic counseling for approximately 1000 families and, currently under the Plan Esperanza, which is a cancer-specific public insurance, they have been able to recommend and cover risk-reduction interventions to their patients with a personal history of cancer and cancer-associated mutations ${ }^{60}$.

\section{Uruguay}

The Uruguayan Collaborative Group is a non-profit organization aimed at providing clinical genetics services to Uruguayan patients with hereditary cancers. This group is composed by clinicians who offer free GCRA in 
several hospitals throughout the country. In 2013, it was recognized by the ministry of Health, which provided funds for the group's operation. It has provided genetics services to approximately 14,000 patients ${ }^{61}$.

\section{CANCER GENETICS TRAINING IN LATIN AMERICA}

The rapidly evolving scientific evidence behind cancer genomics increases the challenges faced by practitioners aiming to integrate it into their everyday medical practice. GCRA is a highly specialized discipline that requires knowledge of both genetics and oncology and specialized patient and family counseling ${ }^{62}$. However, opportunities for formal training in GCRA are limited even in the USA, and they are practically unavailable for those practitioners living in low- and middle-income countries ${ }^{62}$. As a matter of fact, practitioners from Latin America have stated that knowledge about GCRA is limited among patients and physicians, and that there is a lack of training and expertise in the field ${ }^{53}$. However, collaborative efforts aimed at helping providers from low- and middleincome countries overcome barriers to training and establishing effective GCRA programs have been established. One example of a successful international educational program is the Intensive Course in Cancer Risk Assessment organized by the Division of Clinical Cancer Genomics at City of Hope Comprehensive Cancer Center. This course is designed to train practitioners from underserved geographic areas, including Latin America, to integrate cancer genetics and oncology knowledge into their everyday clinical practice ${ }^{62}$. As of 2015, 48 practitioners from Latin America have taken the course and they continue to be involved in other web-based educational sessions, including a multidisciplinary case review conference, topic sessions, and an annual cancer genetic conference ${ }^{63}$.

\section{CONCLUSIONS}

As we have shown, cancer genetics is largely underdeveloped in Latin America ${ }^{64,65}$, and Latin American populations are poorly represented in genomic studies. Therefore, there is a great need to develop policies aimed at increasing the availability of clinical cancer genetics, as well as of research to better understand the prevalence, risks, and outcomes of hereditary cancer in the region.
In spite of these challenges, some successful GCRA models have emerged in some Latin American countries. In order to overcome these barriers, policy makers and healthcare authorities should:

- Increase training and awareness in clinical cancer genetics across all healthcare professions.

- Integrate GCRA programs into the existing cancer care structure and embed GCRA into existing cancer centers and cancer control programs.

- Include GCRA in healthcare policies and plans and include genetic testing and risk reduction interventions into existing healthcare coverage programs.

Advances in the field of genomics over the last years have led to substantial reduction in the cost of genome sequencing. As a result, genome sequencing is becoming increasingly affordable, making it potentially more accessible for patients in developing countries, including those in Latin America ${ }^{66}$. In fact, several commercial laboratories offering genetic testing in the USA have recently expanded their operations to Latin American countries. Nevertheless, even though testing may soon be available and more affordable, the cost of risk reducing strategies may still represent a barrier for the management of hereditary cancer syndromes. This is exemplified by the fact that while the cost of genome sequencing is gradually descending, the cost of breast cancer drugs is rapidly rising ${ }^{67}$. Policymakers in Latin America, where resources are limited, need to carefully balance the benefits and costs of interventions in the rationale of cancer care.

In summary, there is an urgent regional need for the development and implementation of genetic cancer risk assessment programs. Improving the education of the healthcare personnel, a better allocation of existing resources, and the development of healthcare policies aimed at increasing the availability of genetic testing and counseling and cancer prevention are of the highest priority.

\section{REFERENCES}

1. International Agency for Research on Cancer. Globocan 2012 Estimated Cancer Incidence, Mortality and Prevalence Worldwide in 2012. World Health Organization (WHO); 2012 (July 18, 2014); Available at: http://globocan.iarc.fr/Pages/fact_ sheets_population.aspx. 
2. Anderson BO, Cazap E, El Saghir NS, et al. Optimisation of breast cancer management in low-resource and middle-resource countries: executive summary of the Breast Health Global Initiative consensus, 2010. Lancet Oncol. 2011;12:387-98.

3. Goss PE, Lee BL, Badovinac-Crnjevic T, et al. Planning cancer control in Latin America and the Caribbean. Lancet Oncol. 2013; 14:391-436.

4. Villarreal-Garza C, Aguila C, Magallanes-Hoyos MC, et al. Breast cancer in young women in Latin America: an unmet, growing burden. Oncologist. 2013;18:1298-306

5. Perou CM. Molecular stratification of triple-negative breast cancers. Oncologist. 2011;16:61-70.

6. Siegel RL, Miller KD, Jemal A. Cancer statistics, 2016. CA Cancer J Clin. 2016;66:7-30

7. Strasser-Weippl K, Chavarri-Guerra Y, Villarreal-Garza C, et al. Progress and remaining challenges for cancer control in Latin America and the Caribbean. Lancet Oncol. 2015;16: 1405-38.

8. Ford D, Easton DF, Stratton M, et al. Genetic heterogeneity and penetrance analysis of the BRCA1 and BRCA2 genes in breast cancer families. Am J Hum Genet. 1998;62:676-89.

9. Mavaddat N, Peock S, Frost D, et al. Cancer risks for BRCA1 and BRCA2 mutation carriers: results from prospective analysis of EMBRACE. J Natl Cancer Inst. 2013;105:812-22.

10. Dutil J, Golubeva VA, Pacheco-Torres AL, Diaz-Zabala HJ, Matta JL, Monteiro AN. The spectrum of BRCA1 and BRCA2 alleles in Latin America and the Caribbean: a clinical perspective. Breast Cancer Res Treat. 2015;154:441-53.

11. Weitzel J, Clague J, Ogaz R, et al., editors. Prevalence and ancestral origin of Hispanic BRCA mutations: Insights for ancestry informed genetic cancer risk assessment. ASCO Annual Meeting; 2011; Chicago, IL.

12. NCCN. NCCN Genetic/Familial High-Risk Assessment: Breast and Ovarian Version 2.20172017. Available at: https://www. nccn.org/professionals/physician gls/recently updated.asp.

13. Tan DS, Mok TSK, Rebbeck TR. Cancer genomics: Diversity and disparity across ethnicity and geography. J Clin Oncol. 2016;34:91-101.

14. Adhikari K, Mendoza-Revilla J, Chacon-Duque JC, Fuentes-Guajardo M, Ruiz-Linares A. Admixture in Latin America. Curr Opin Genet Dev. 2016;41:106-14.

15. Ruiz-Linares A, Adhikari K, Acuna-Alonzo V, et al. Admixture in Latin America: geographic structure, phenotypic diversity and self-perception of ancestry based on 7,342 individuals. PLoS Genet. 2014;10:e1004572

16. Fejerman L, Chen GK, Eng $C$, et al. Admixture mapping identifies a locus on 6 q25 associated with breast cancer risk in US Latinas. Hum Mol Genet. 2012;21:1907-17.

17. Narod S, Foulkes W. BRCA1 and BRCA2: 1994 and beyond. Nat Rev Cancer. 2004;4:665-76.

18. Abeliovich D, Kaduri L, Lerer I, et al. The founder mutations 185delAG and 5382insC in BRCA1 and 6174delT in BRCA2 appear in $60 \%$ of ovarian cancer and $30 \%$ of early-onset breast cancer among Ashkenazi women. Am J Hum Genet. 1997;60: 505-14.

19. Prevalence and penetrance of BRCA1 and BRCA2 mutations in a population-based series of breast cancer cases. Anglian Breast Cancer Study Group. Br J Cancer. 2000;83:1301-8.

20. Donenberg T, Lunn J, Curling D, et al. A high prevalence of BRCA1 mutations among breast cancer patients from the Bahamas. Breast Cancer Res Treat. 2011;125:591-6.

21. Trottier M, Lunn J, Butler R, et al. Prevalence of founder mutations in the BRCA1 and BRCA2 genes among unaffected women from the Bahamas. Clin Genet. 2016;89:328-31.

22. Gutierrez Espeleta GA, Llacuachaqui M, Garcia-Jimenez L, et al. BRCA1 and BRCA2 mutations among familial breast cancer patients from Costa Rica. Clin Genet. 2012;82:484-8.

23. Rodriguez RC, Esperon AA, Ropero R, et al. Prevalence of BRCA1 and BRCA2 mutations in breast cancer patients from Cuba. Fam Cancer. 2008;7:275-9.

24. Dutil J, Colon-Colon JL, Matta JL, Sutphen R, Echenique M. Identification of the prevalent BRCA1 and BRCA2 mutations in the female population of Puerto Rico. Cancer Genet. 2012;205:242-8.

25. Delgado L, Fernandez G, Grotiuz G, et al. BRCA1 and BRCA2 germline mutations in Uruguayan breast and breast-ovarian cancer families. Identification of novel mutations and unclassified variants. Breast Cancer Res Treat. 2011;128:211-8.

26. Santos $C$, Peixoto $A$, Rocha $P$, et al. Haplotype and quantitative transcript analyses of Portuguese breast/ovarian cancer families with the BRCA1 R71G founder mutation of Galician origin. Fam Cancer. 2009;8:203-8.
27. Vega A, Campos B, Bressac-De-Paillerets B, et al. The R71G BRCA1 is a founder Spanish mutation and leads to aberrant splicing of the transcript. Hum Mutat. 2001;17:520-1.

28. Weitzel JN, Lagos VI, Herzog JS, et al. Evidence for common ancestral origin of a recurring BRCA1 genomic rearrangement identified in high-risk Hispanic families. Cancer Epidemiol Biomarkers Prev. 2007:16:1615-20.

29. Torres D, Rashid MU, Gil F, et al. High proportion of BRCA1/2 founder mutations in Hispanic breast/ovarian cancer families from Colombia. Breast Cancer Res Treat. 2007;103:225-32.

30. Rodríguez AO, Llacuachaqui M, Pardo GG et al. BRCA1 and BRCA2 mutations among ovarian cancer patients from Colombia. Gynecol Oncol. 2012;124:236-43.

31. Machado PM, Brandao RD, Cavaco BM, et al. Screening for a BRCA2 rearrangement in high-risk breast/ovarian cancer families: evidence for a founder effect and analysis of the associated phenotypes. J Clin Oncol. 2007;25:2027-34.

32. Ashton-Prolla $P$, Vargas FR. Prevalence and impact of founder mutations in hereditary breast cancer in Latin America. Genet Mol Biol. 2014;37:234-40

33. Judkins $T$, Rosenthal $E$, Arnell $C$, et al. Clinical significance of large rearrangements in BRCA1 and BRCA2. Cancer. 2012;118: 5210-6

34. Weitzel JN, Clague J, Martir-Negron A, et al. Prevalence and type of BRCA mutations in Hispanics undergoing genetic cancer risk assessment in the southwestern United States: a report from the Clinical Cancer Genetics Community Research Network. ] Clin Oncol. 2013;31:210-6.

35. Custodio G, Parise GA, Kiesel Filho N, et al. Impact of neonatal screening and surveillance for the TP53 R337H mutation on early detection of childhood adrenocortical tumors. J Clin Oncol. 2013;31:2619-26.

36. Garritano S, Gemignani F, Palmero El, et al. Detailed haplotype analysis at the TP53 locus in p.R337H mutation carriers in the population of Southern Brazil: evidence for a founder effect. Hum Mutat. 2010;31:143-50

37. Antoniou AC, Casadei S, Heikkinen T, et al. Breast-cancer risk in families with mutations in PALB2. N Engl J Med. 2014;371:497506.

38. Catucci I, Casadei S, Ding YC, et al. Haplotype analyses of the c. 1027 C $>$ T and c. 21672168 delAT recurrent truncating mutations in the breast cancer-predisposing gene PALB2. Breast Cancer Res Treat. 2016;160:121-9.

39. Weitzel JN, Blazer KR, MacDonald DJ, Culver JO, Offit K. Genetics, genomics and cancer risk assessment: state of the art and future directions in the era of personalized medicine. CA Cancer J Clin. 2011;61:327-59

40. Cruz-Correa M, Perez-Mayoral J, Dutil J, Echenique M, Mosquera R, Rivera-Roman K, et al. Clinical Cancer Genetics Disparities among Latinos. J Genet Couns. 2016. [Epub ahead of print].

41. Breastcancer.org. Genetic Testing Facilities and Cost. Ardmore, PA. Available at: http://www.breastcancer.org/symptoms/testing/genetic/facility cost. [Accessed January 10, 2017].

42. Margarit S. Cáncer Hereditario de Mama. Rev Chil Rad. 2008;14:135-41.

43. Villarreal-Garza $C$, Herrera LA, Herzog J, et al Significant Clinica impact of recurrent BRCA1 and BRCA2 (BRCA) mutations in Mexico. Cancer Res. 2015;121:372-8.

44. Abugattas J, Llacuachaqui $M$, Allende YS, et al. Prevalence of BRCA1 and BRCA2 mutations in unselected breast cancer patients from Peru. Clin Genet. 2015;88:371-5.

45. Hernandez JE, Llacuachaqui M, Palacio G, et al. Prevalence of BRCA1 and BRCA2 mutations in unselected breast cancer patients from Medellin, Colombia. Hered Cancer Clin Pract. 2014;12:11.

46. Villarreal-Garza C, Weitzel JN, Llacuachaqui M, et al. The prevalence of BRCA1 and BRCA2 mutations among young Mexican women with triple-negative breast cancer. Breast Cancer Res Treat. 2015;150:389-94.

47. Herzog J, Castillo D, Slavin T, et al., editors. Sequencing for All: An Economical Workflow for BRCA Genotyping of Breast and Ovarian Cancer in Underserved Women from Latin America ASHG 2016; The American Society of Human Genetics.

48. ESE INdC, G -, Orden Ly, COLCIENCIAS LyO, Departamento Administrativo de Ciencia Tel. Guía de práctica clínica (GPC) para la detección temprana, tratamiento integral, seguimiento y rehabilitación del cáncer de mama Sistema General de Seguridad Social en Salud - Colombia Guía Completa. 2013.

49. Para la prevención, diagnóstico, tratamiento, control y vigilancia epidemiológica del cáncer de mama, NORMA Oficial Mexicana. NOM-041-SSA2-2011. 
50. Seuánez HN, Vargas FR, Moreira M, et al. Rede Nacional De Cancer Familial Manual Operacional. Rio de Janeiro. Instituto Nacional de Câncer - INCA, 2009.

51. Núñez LM, Pesce V, Viniegra M, Buffa R, Tabares G. Pautas para la Detección y Estudio de Casos con Alto Riesgode Cáncer de Mama Heredo-Familiar. In: Salud. NdCMd, editor. Argentina. 2014.

52. Margarit SB, Alvarado M, Alvarez K, Lay-Son G. Medical Genetics and Genetic Counseling in Chile. J Genet Couns. 2013:22:869-74.

53. Chavez T, Nehoray B, Obregon-Tito A, et al. Exploring the climate, barriers, and possible approaches to implementing genetic cancer risk assessment in Latin America: A roundtable discussion. Cancer Epidemiol Biomarkers Prev. 2015;24:A36

54. Red Argentina de Cancer Familiar (RACAF). Reporte Anual. Buenos Aires - República Argentina: Instituto Nacional del Cáncer; 2015; Available at: http://www.msal.gov.ar/inc/recursos-decomunicacion/primer-reporte-anual-de-la-red-argentina-decancer-familiar-racaf/.

55. Ashton-Prolla P, Seuanez HN. The Brazilian Hereditary Cancer Network: historical aspects and challenges for clinical cancer genetics in the public health care system in Brazil. Genet Mol Biol. 2016;39:163-5.

56. Incan inagura clínica para detectar cáncer hereditario. Mexico City 2016. Available at: http://www.milenio.com/cultura/Incan inaugura_clinica-detectar_cancer_hereditario_0_689331091. html [Accessed 6 March 2017].

57. Investiga predisposición genética al cáncer de mama. Noticias del Tecnológico de Monterrey Monterrey, NL 2017. Available at: http://www.itesm.mx/wps/wcm/connect/snc/portal+informativo /por+campus/monterrey/academia/n552025 [Accessed 6 March 2017].

58. Aceves W. Investigadores del CUCS estudian predisposición genética en cáncer de mama. Guadalajara, Jal: Universidad de Guadalajara; 2015. Available at: http://www.udg.mx/es/noticia/investigadores-del-cucs-estudian-predisposicion-geneticaen-cancer-de-mama [Accessed January 10, 2017].

59. Weitzel JN, Villarreal-Garza C, Blazer KR, et al., editors. Dissemination and implementation of genomic cancer risk assessment in Latin America via innovative pairing of clinical training and genomic tools. American Association for Cancer Research (AACR) Annual Meeting 2016; New Orleans.

60. Manrique JE, Sullcahuamán-Allende Y, Limache-García A. Asesoría genética sobre cáncer en el Perú. Revista Peruana de Medicina Experimental y Salud Pública. 2013;30:118-23.

61. Fundación Génesis Uruguay. Mira el programa de "37 Grados" sobre el cáncer hereditario. Available at: http://www.fundaciongenesis.org.uy/es/. [Accessed February 25, 2017].

62. Blazer KR, MacDonald DJ, Ricker C, Sand S, Uman GC, Weitzel $\mathrm{JN}$. Outcomes from intensive training in genetic cancer risk counseling for clinicians. Genet Med. 2005:7:40-7.

63. Blazer KR, Nehoray B, Solomon I, et al. Leveraging the Resources of an Innovative Clinical Cancer Genetics Training Program to Address Disparities in Cancer Prevention and Control in Latin America. International Cancer Education Conference: Cancer Education in Diverse Populations: Disparities, Genomics $\&$ Innovations, 2015, abst.

64. Palmero El, Alemar B, Schuler-Faccini L, et al Screening for germline BRCA1, BRCA2, TP5 3 and CHEK2 mutations in families at-risk for hereditary breast cancer identified in a population-based study from Southern Brazil. Genet Mol Biol. 2016:39:210-22.

65. Lynce F, Graves KD, Jandorf L, et al. Genomic disparities in breast cancer among Latinas. Cancer Control. 2016;23:359-72.
66. NHGRI. The Cost of Sequencing a Human Genome. 2017. Available at: https://www.genome.gov/sequencingcosts/. [Accessed February 25, 2017]

67. Kantarjian H, Steensma D, Rius Sanjuan J, Elshaug A, Light D. High cancer drug prices in the United States: reasons and proposed solutions. J Oncol Pract. 2014;10:e208-11.

68. Solano AR, Aceto GM, Delettieres D, et al. BRCA1 and BRCA2 analysis of Argentinean breast/ovarian cancer patients selected for age and family history highlights a role for novel mutations of putative south-American origin. SpringerPus. 2012:1:20.

69. Solano AR, Cardoso FC, Romano V, et al. Spectrum of BRCA1/2 variants in 940 patients from Argentina including novel, deleterious and recurrent germline mutations: impact on healthcare and clinical practice. Oncotarget. 2016. [Epub ahead of print].

70. Gomes M, Costa M, Borojevic R, et al. Prevalence of BRCA1 and BRCA2 mutations in breast cancer patients from Brazil. Breast Cancer Res Treat. 2007:103:349-53.

71. Maistro S, Teixeira N, Encinas G, et al. Germline mutations in BRCA1 and BRCA2 in epithelial ovarian cancer patients in Brazil. BMC Cancer. 2016;16:934

72. Felix GE, Abe-Sandes C, Machado-Lopes TM, et al. Germline mutations in BRCA1, BRCA2, CHEK2 and TP53 in patients at high-risk for HBOC: characterizing a Northeast Brazilian Population. Hum Genome Var. 2014:1:14012.

73. Silva FC, Lisboa BC, Figueiredo MC, et al. Hereditary breast and ovarian cancer: assessment of point mutations and copy number variations in Brazilian patients. BMC Med Genet. 2014.15.55.

74. Esteves VF, Thuler LC, Amendola LC, et al. Prevalence of BRCA1 and BRCA2 gene mutations in families with medium and high risk of breast and ovarian cancer in Brazil. Braz J Med Biol Res. 2009:42:453-7.

75. Dufloth RM, Carvalho S, Heinrich JK, et al. Analysis of BRCA1 and BRCA2 mutations in Brazilian breast cancer patients with positive family history. Sao Paulo Med J. 2005:123:192-7.

76. Gallardo $M$, Silva $A$, Rubio $L$, et al. Incidence of BRCA1 and BRCA2 mutations in 54 Chilean families with breast/ovarian cancer, genotype-phenotype correlations. Breast Cancer Res Treat. 2006;95:81-7.

77. Gonzalez-Hormazabal P, Gutierrez-Enriquez S, Gaete D, et al. Spectrum of BRCA $1 / 2$ point mutations and genomic rearrangements in high-risk breast/ovarian cancer Chilean families. Breast Cancer Res Treat. 2011:126:705-16.

78. Jara L, Ampuero S, Santibanez E, et al. BRCA1 and BRCA2 mutations in a South American population. Cancer Genet Cytogenet. 2006:166:36-45

79. Sanchez A, Faundez P, Carvallo P. Genomic rearrangements of the BRCA1 gene in Chilean breast cancer families: an MLPA analysis. Breast Cancer Res Treat. 2011;128:845-53.

80. Vaca-Paniagua F, Alvarez-Gomez RM, Fragoso-Ontiveros V, et al Full-Exon pyrosequencing screening of BRCA germline mutations in Mexican women with inherited breast and ovarian cancer. PloS One. 2012:7:e37432

81. Ruiz-Flores P, Sinilnikova OM, Badzioch $M$, et al. BRCA1 and BRCA2 mutation analysis of early-onset and familial breast cancer cases in Mexico. Hum Mutat. 2002:20:474-5.

82. Torres-Mejía G, Royer R, Llacuachaqui M, et al. Recurrent BRCAI and BRCA2 mutations in Mexican women with breast cancer. Cancer Epidemiol Biomarkers Prev. 2015;24:498-505

83. Lara K. Consigliere N, Perez J, Porco A. BRCA1 and BRCA2 mutations in breast cancer patients from Venezuela. Biol Res. 2012; 45:117-30. 